\title{
ANALISIS KOMPARATIF KINERJA KEUANGAN ANTARA BANK SYARIAH DAN BANK KONVENSIONAL BERDASARKAN METODE CAMEL
}

\author{
Armanto Witjaksono $^{1}$; Anis Yunistriani ${ }^{2}$ \\ ${ }^{1,2}$ Jurusan Akuntansi, Fakultas Ekonomi dan Bisnis, Bina Nusantara University \\ Jln. K.H. Syahdan No. 9, Kemanggisan, Palmerah, Jakarta Barat 11480
}

\begin{abstract}
The main objective of this paper is to give an overview of comparative financial performance of Islamic banks with conventional banks based on the CAMEL method. The main question would be answered to know there is difference in the performance of conventional banking and Islamic banking are analyzed by using the ratio CAMEL. To prove the hypothesis that there is no significant difference between the bank's financial performance Islamic and conventional banks (Ho) or there are significant differences between the financial performance of Islamic banks and conventional banks (Hi). Researchers used a parametric statistical technique, which consists of test data normality using the Kolmogorov Smirnov test and $Q Q$ plots, test of homogeneity using the F test (Levene's Test), and Independent Sample T-Test with significant value 5\% confidence level $(1-\alpha)=$ 95\%. The results showed that the ratio of data CAMEL Islamic banks and conventional banks in normal distribution and homogeneous. Then it can be concluded that the variable CAR, NPL, and LDR between conventional banks and Islamic banks have significant differences, while the ROA and ROE of the two types of banking industry is not significantly different or relatively the same.
\end{abstract}

Keywords: conventional bank, sharia bank, CAMEL ratio

\begin{abstract}
ABSTRAK
Tujuan utama dari paper ini adalah untuk memberi gambaran umum perbandingan kinerja keuangan bank syariah dengan bank konvensional berdasarkan metode CAMEL. Adapun pertanyaan utama yang hendak dijawab untuk mengetahui perbedaan kinerja perbankan konvensional dan perbankan syariah yang dianalisa dengan menggunakan rasio CAMEL. Untuk membuktikan hipotesis bahwa tidak ada perbedaan yang signifikan kinerja keuangan antara bank syariah dan bank konvensional (Ho) atau ada perbedaan yang signifikan kinerja keuangan antara bank syariah dan bank konvensional (Hi), peneliti menggunakan teknik statistik parametrik, yang terdiri dari uji normalitas data menggunakan uji Kolmogrov Smirnov dan Q-Q Plot, uji homogenitas menggunakan uji $F$ (Levene's Test), dan Independent Sample T-Test dengan nilai signifikan $5 \%$ dan tingkat keyakinan $(1-\alpha)=95 \%$. Hasil penelitian diperoleh bahwa data rasio CAMEL bank syariah dan bank konvensional berdistribusi normal dan homogen.
\end{abstract}

Kata kunci: bank konvensional, bank syariah, metode CAMEL 


\section{PENDAHULUAN}

\section{Latar Belakang Masalah}

Tujuan fundamental perbankan syariah mengacu pada pendapat Tim Pengembangan Perbankan Syariah, Institute Bankir Indonesia (2003), adalah untuk mendorong dan mempercepat kemajuan ekonomi suatu masyarakat dengan melakukan kegiatan perbankan, financial, komersial, investasi sehingga meningkatkan kesempatan kerja dan kesejahteraan ekonomi sesuai dengan syariah islam. Berdasarkan Mudrajat (2002), tujuan bisnis perbankan syariah tidak berbeda dengan perbankan konvensional yaitu memperoleh keuntungan optimal dengan jalan memberikan layanan jasa keuangan kepada masyarakat dengan menggunakan prinsip syariah. Bagi pemilik saham menanamkan modalnya pada bank dengan tujuan untuk memperoleh penghasilan berupa deviden atau mendapatkan keuntungan melalui meningkatnya harga pasar saham yang dimilikinya. Mengacu pada Susilo (2000), bank yang selalu dapat menjaga kinerjanya dengan baik terutama tingkat profitabilitasnya yang tinggi dan mampu membagikan deviden dengan baik serta prospek usahanya selalu berkembang dan dapat memenuhi ketentuan prudential banking regulation dengan baik, maka ada kemungkinan nilai saham dari bank yang bersangkutan di pasar sekunder dan jumlah dana pihak ketiga ini merupakan salah satu indikator naiknya kepercayaan masyarakat kepada bank yang bersangkutan.

Sabi (1996) melakukan penelitian perbandingan kinerja bank antara bank domestik dan bank asing pada masa transisi, menuju ekonomi yang berorientasi pasar (market oriented economy) di Hungaria periode 1992-1993. Ukuran kinerja yang digunakan adalah rasio keuangan yang dibagi dalam tiga kelompok, yaitu profitabilitas, likuiditas, dan komitmen terhadap ekonomi domestik. Signifikansi perbedaan kinerja tersebut diuji dengan students and Kruskal Wallis test. Hasil penelitian menunjukkan bahwa dibandingkan dengan bank lokal profitabilitas bank asing lebih tinggi sedangkan likuiditas dan penyaluran kredit berisiko lebih kecil. Penelitian tersebut menjadi rujukan bagi Chantapong (2003) untuk membandingkan kinerja bank domestik dengan bank asing di Thailand setelah krisis keuangan melanda asia tenggara pada tahun 1997. data yang digunakan adalah rasio keuangan, yang dihitung dari dua kelompok bank selama periode 1995-2000. Signifikansi perbedaan kedua jenis bank diuji dengan analisis regresi menggunakan Generalized Least Square (GLS). Hasil penelitian menunjukkan bahwa bank asing mempunyai tingkat profitabilitas lebih tinggi dibandingkan dengan bank domestik.

Namun demikian angka profitabilitas bank asing dan bank domestik di Thailand menunjukkan peningkatan sebelum krisis, bahkan perbedaan tersebut semakin kecil atau bahkan tidak ada perbedaan setelah krisis. Samad \& Hasan (2000), melengkapi penelitian Sabi (1996) dengan menggabungkan metode inter-temporal analysis dan inter-bank analysis. Metode inter-temporal analysis digunakan untuk membandingkan kinerja bank islam Malaysia Berhad (BIMB) pada awal dan akhir pendiriannya. Signifikansi perbedaan diuji dengan t-test. Hasilnya menunjukkan bahwa ROA dan ROE akhir periode lebih baik dibandingkan awal periode. Sesuai dengan prinsip high risk high return, tingginya profitabilitas di akhir periode diduga karena porsi pembiayaan (mudharabah dan musyarakah) semakin membesar. Adapun inter-bank analysis digunakan untuk membandingkan kinerja BIMB dengan delapan bank konvensional di Malaysia selama periode 1984-1997. signifikansi perbedaan diuji dengan F-test (ANOVA). Hasilnya menunjukkan bahwa BIMB mempunyai likuiditas relatif baik dan resiko lebih kecil dibandingkan delapan bank konvensional. 


\section{METODE PENELITIAN}

\section{Landasan Teori}

\section{Capital (rasio permodalan / kecukupan modal)}

Menurut Bank Indonesia (2004), modal merupakan salah satu rasio yang sangat vital dan sangat penting untuk menunjang pengembangan usaha dan penanggulangan resiko kerugian yang mungkin ditanggung oleh bank dalam menjalankan operasionalnya sangat bergantung pada modal yang dimilikinya. Menurut Zainuddin \& Hartono (1999), Capital Adequacy Ratio adalah kecukupan modal yang menunjukkan kemampuan bank dalam mempertahankan modal yang mencukupi dan kemampuan manajemen bank dalam mengidentifikasi, mengukur, mengawasi, dan mengontrol resikoresiko yang timbul yang dapat berpengaruh terhadap besarnya modal bank.

Rumus perhitungan CAR adalah :

Capital Adequacy Ratio $(\mathrm{CAR})=$ modal inti + modal pelengkap $\quad \mathrm{x} 100 \%$

Aktiva tertimbang menurut resiko (ATMR)

\section{Assets Quality (rasio kualitas asset)}

Menurut Zainuddin \& Hartono (1999), asset Quality menunjukan hubungan kualitas asset sehubungan dengan resiko kredit yang dihadapi bank akibat pemberian kredit dan investasi dana bank pada portofolio yang berbeda. Menurut Syahyunan (2004), aktiva yang produktif ,karena penempatan dana bank tersebut di atas adalah untuk mencapai tingkat penghasilan yang diharapkan. Ada empat macam aktiva produktif, antara lain: kredit yang diberikan, surat-surat berharga, penempatan dana pada bank lain, penyertaan, prospek usaha, kondisi keuangan dengan penekanan pada arus kas debitur, dan kemampuan membayar.

Berdasarkan faktor-faktor tersebut, kredit yang diberikan bank kepada nasabah dapat dibedakan menjadi lima kelompok kolektibilitas. Berikut ini kelompok kolektibilitas yang dinilai berdasarkan kemampuan membayar: lancar, dalam perhatian khusus, kurang lancar, diragukan, macet. Dari kelompok kolektibilitas tersebut, yang terakhir merupakan kredit macet atau NPL (non performing loan). Besaran NPL ditujukan dengan persentase perbandingan kredit bermasalah dengnan seluruh kredit atau pembiayaan yang dikucurkan bank. Walaupun peraturan kap bagi bank syariah telah dikeluarkan, yaitu peraturan bank indonesia nomor 5/7/PBI/2003 tanggal 19 mei 2003 tentang kwalitas aktiva produktif bagi bank syariah dalam menghitung NPL peneliti masih menggunakan ketentuan SK direktur BI tersebut di atas. Rumus perhitungan NPL $=\quad \begin{aligned} & \text { kredit yang bermasalah } \\ & \text { total kredit yang dikucurkan }\end{aligned} \times 100 \%$

NPL atau tingkat kredit macet menunjukan berapa persen kredit yang bermasalah dari keseluruhan kredit ysng mereka kucurkan ke masyarakat. NPL juga merupakan faktor yang sangat penting bagi penilaian kinerja perbankan, bahkan hampir semua rasio nilainya dipengaruhi oleh NPL.

\section{Management (Rasio Management )}

Menurut Zainuddin \& Hartono (1999), kualitas manajemen menunjukan kemampuan management bank untuk mengidentifikasi, mengawasi, mengontrol resiko-resiko yang timbul melalui kebijakan-kebijakan dan strategi bisnisnya untuk mencapai target. 


\section{Earning (Rasio Rentabilitas)}

Menurut Zainuddin \& Hartono (1999) rasio rentabilitas menunjukan kemampuan bank dalam meningkatkan laba usahanya yang dicapai. Bank yang mempunyai kinerja baik adalah bank yang diukur secara rentabilitas yang terus meningkat. Dalam penelitian ini rasio rentabilitas yang digunakan adalah ROA dan ROE.

\section{ROA (Return on Asset)}

Return On Asset $=\quad$ Laba Sebelum Pajak $\times 100 \%$ Total Asset

\section{ROE (Return on Equity)}

ROE (Return on Equity) atau pengembalian atas ekuitas. Rasio ini mempunyai arti yang sangat penting untuk mengukur kemampuan dalam menajemen dalam mengelola modal yang tersedia untuk mendapatkan net income. Rumus perhitungan ROE yaitu:

$$
\text { Return On Equity }=\quad \frac{\text { Laba Sebelum Pajak }}{\text { Modal pemegang saham biasa }} \times 100 \%
$$

\section{Liquidity (Rasio Likuiditas)}

Menurut Zainuddin \& Hartono (1999), likuiditas menunjukan ketersediaan dana dan sumber dana bank pada saat ini dan masa yang akan datang, pengaturan liquiditas bank terutama dimaksudkan agar setiap bank setiap saat dapat memenuhi kewajiban-kewajiban yang harus segera dibayar. Rasio liquiditas adalah rasio yang menunjukan kemampuan perusahaan dalam memenuhi kewajiban jangka pendeknya termasuk kewajiban jangka panjang yang telah berubah menjadi kewajiban jangka pendek. Salah satu rasio yang digunakan dalam penelitian ini adalah FDR (Finance to Deposit Rasio) atau Loan to Deposit Ratio (LDR). Rasio ini memberikan indikasi mengenai jumalh dana pihak ketiga yang disalurkan dalam bentuk kredit (pembiayaan). Hal ini penting mengingat lembaga perbankan secara operasional mendasarkan kemampuan operasionalnya pada kredibilitas, khususnya dalam mengatur kondisi liquiditasnya.

Rumus perhitungan FDR/LDR $=\frac{\text { Kredit (pembiayaan) }}{\text { Dana pihak ketiga }} \times 100 \%$

\section{HASIL DAN PEMBAHASAN}

\section{Pengujian Normalitas Data}

\section{CAR}

Tabel 1 CAR

\begin{tabular}{llr}
\hline \multicolumn{2}{l}{ One-Sample Kolmogorov-Smirnov Test } \\
N & & CAR \\
Normal Parameters(a,b) & Mean & 12 \\
& Std. Deviation & 24.04666667 \\
Most Extreme Differences & Absolute & 9.559630397 \\
& Positive & 0.212975362 \\
& Negative & 0.17936598 \\
Kolmogorov-Smirnov Z & & -0.212975362 \\
Asymp. Sig. (2-tailed) & & 0.737768297 \\
\hline A & Test distribution is Normal. & 0.647783541 \\
B & Calculated from data. \\
\end{tabular}


Dalam uji normalitas data pada Current Adequacy Ratio (CAR), diperoleh nilai $\mathrm{K}$ hitung adalah 0.7377768297 dengan nilai signifikan $\alpha=5 \%$, adalah 0.647783541 . Rasio ini memperoleh nilai $\mathrm{P}$ value $>$ dari 0.05 , sehingga dapat disimpulkan bahwa hipotesis Ho diterima yakni data tersebut berdistribusi normal. Selain itu, melihat gambar Q-Q Plot atau penyebaran data (titik) pada sumbu diagonal grafik, data menyebar disekitar garis normal maka sampel mempunyai data yang berdistribusi normal.

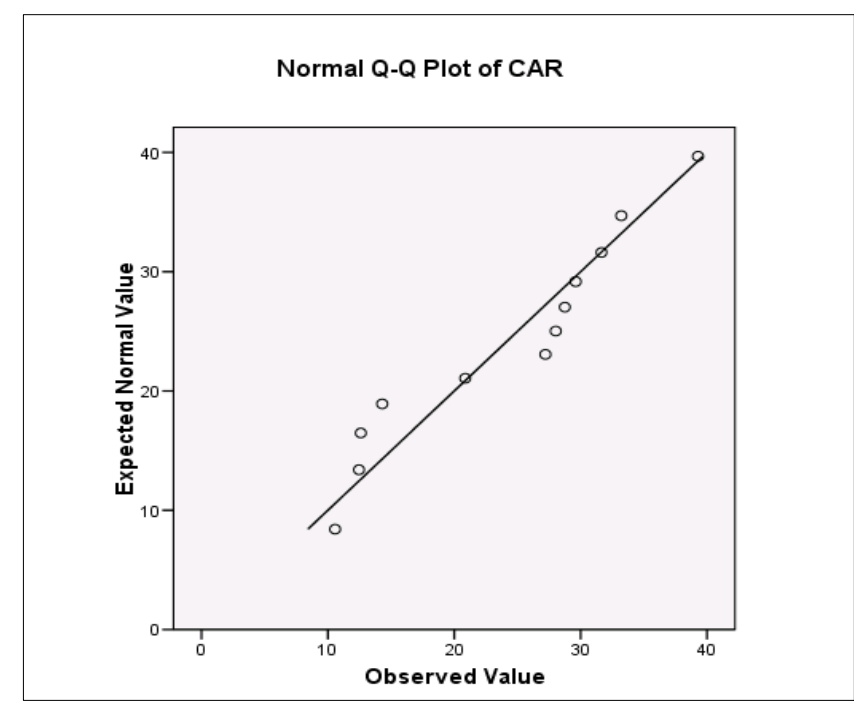

Gambar 1 Normal Q-Q Plot of CAR

NPL

Tabel 2 One-Sample Kolmogorov-Smirnov Test

\begin{tabular}{llr}
\hline & & NPL \\
\hline N & & 12 \\
Normal Parameters(a,b) & Mean & 4.8775 \\
Most Extreme Differences & Std. Deviation & 1.820045579 \\
& Absolute & 0.170502495 \\
& Positive & 0.170502495 \\
& Negative & -0.12253472 \\
Kolmogorov-Smirnov Z & & 0.590637968 \\
Asymp. Sig. (2-tailed) & & 0.876430988 \\
A & Test distribution is Normal. \\
B & Calculated from data. \\
\hline
\end{tabular}

Dalam uji normalitas data pada Non Performing Loan Ratio (NPL), diperoleh nilai K hitung adalah 0.590637968 dengan nilai signifikan $\alpha=5 \%$, adalah 0.876430988 . Rasio ini memperoleh nilai $\mathrm{P}$ value $>$ dari 0.05 , sehingga dapat disimpulkan bahwa hipotesis Ho diterima bahwa data tersebut berdistribusi normal. Dari rata - rata (mean) NPL disimpulkan distribusi populasi normal karena data menyebar di sekitar garis normal. 


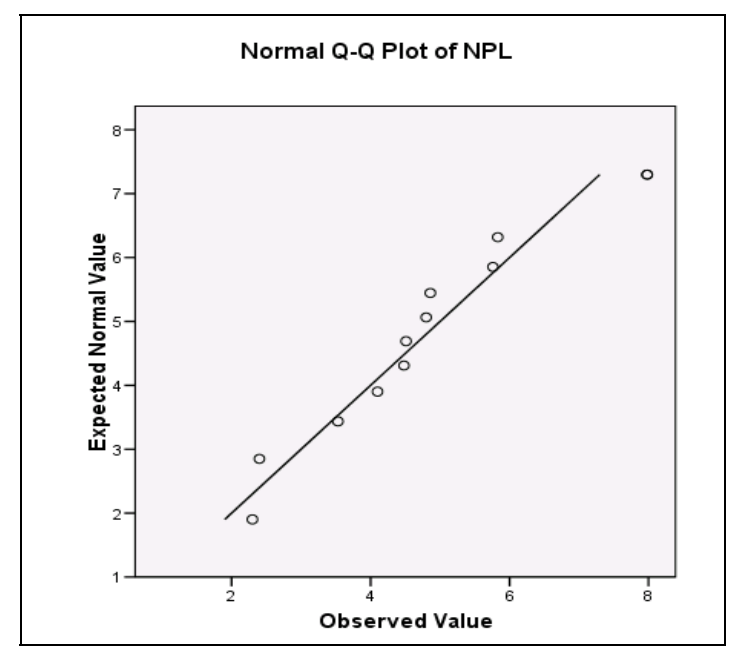

Gambar 2 Normal Q-Q Plot of NPL

\section{ROA}

Tabel 3 One-Sample Kolmogorov-Smirnov Test Uji Normalitas

\begin{tabular}{llr} 
& & \multicolumn{1}{c}{ ROA } \\
\hline N Normal Parameters(a,b) & Mean & 12 \\
& Std. Deviation & 1.859166667 \\
Most Extreme Differences & Absolute & 0.755205671 \\
& Positive & 0.22413446 \\
& & 0.22413446 \\
Kolmogorov-Smirnov Z & Negative & - \\
Asymp. Sig. (2-tailed) & & 0.179548845 \\
\hline A & & 0.776424545 \\
B & Test distribution is Normal. & 0.582930833 \\
\hline & Calculated from data. &
\end{tabular}

Dalam uji normalitas data pada Return On Asset (ROA), diperoleh $\mathrm{K}$ hitung nilai adalah 0.776424545 dengan nilai signifikan $\alpha=5 \%$, adalah 0.582930833 . Rasio ini memperoleh nilai $P$ value $>$ dari 0,05 , sehingga dapat disimpulkan bahwa hipotesis Ho diterima bahwa data tersebut berdistribusi normal.

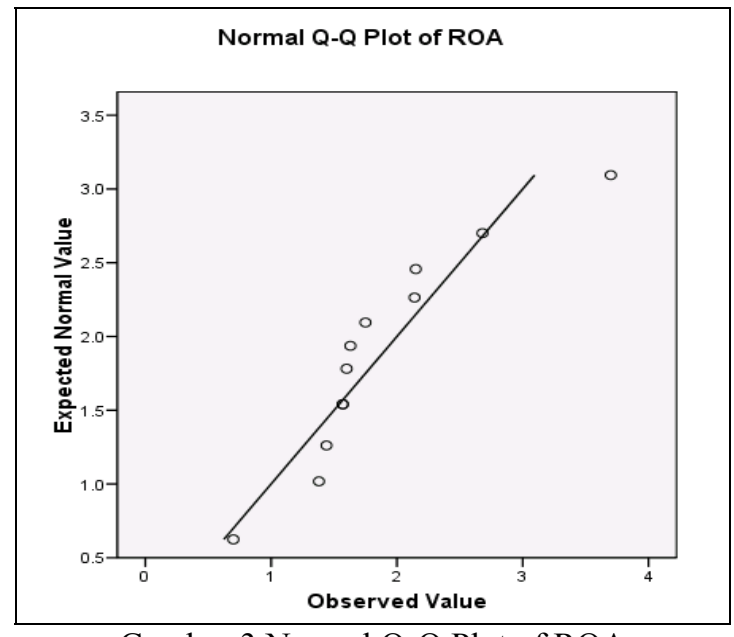

Gambar 3 Normal Q-Q Plot of ROA 
Dari rata-rata (mean) ROA disimpulkan distribusi populasi normal karena penyebaran titik berada sekitar sumbu normal.

\section{ROE}

Tabel 4 One-Sample Kolmogorov-Smirnov Test

\begin{tabular}{llr} 
Uji Normalitas & \\
\hline One-Sample Kolmogorov-Smirnov Test & \multicolumn{1}{l}{ ROE } \\
\hline N & & 12 \\
Normal Parameters(a,b) & Mean & 16.65083333 \\
& Std. Deviation & 12.38765181 \\
Most Extreme Differences & Absolute & 0.192261199 \\
& Positive & 0.192261199 \\
& Negative & -0.134636253 \\
Kolmogorov-Smirnov Z & & 0.666012329 \\
Asymp. Sig. (2-tailed) & & 0.766809047 \\
\hline A & Test distribution is Normal. & \\
B & Calculated from data.
\end{tabular}

Dalam uji normalitas data pada Return On Asset (ROE), diperoleh nilai K hitung 0.666012329 dengan nilai signifikan $\alpha=5 \%$, adalah 0.766809047. Rasio ini memperoleh nilai $\mathrm{P}$ value $>$ dari 0,05 , sehingga dapat disimpulkan bahwa hipotesis Ho diterima bahwa data tersebut berdistribusi normal.

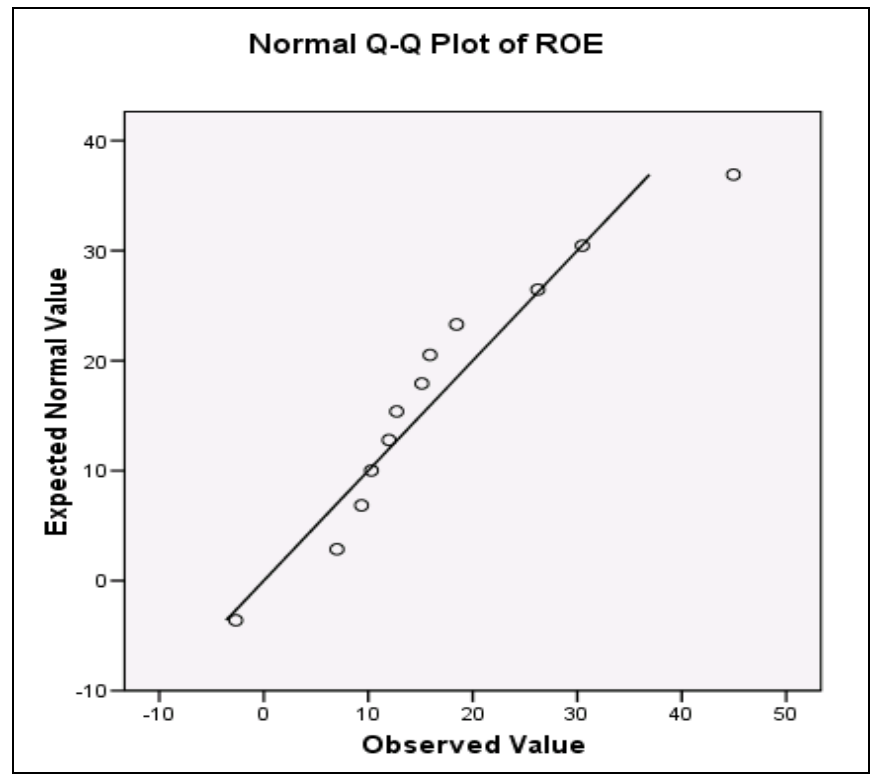

Gambar 4 Normal Q-Q Plot of ROE

Dari rata-rata (mean) ROE disimpulkan data menyebar di sekitar garis diagonal dan mengikuti arah garis normal, maka sampel mempunyai data yang berdistribusi normal. 


\section{LDR}

Tabel 5 LDR

Uji Normalitas
\begin{tabular}{|l|l|r|}
\hline One-Sample Kolmogorov-Smirnov Test & & \multicolumn{1}{|c|}{} \\
N & & 12 \\
Normal Parameters(a,b) & Mean & 83.58916667 \\
& Std. Deviation & 28.71763616 \\
Most Extreme Differences & Absolute & 0.203978772 \\
& Positive & 0.203978772 \\
& Negative & -0.127904845 \\
Kolmogorov-Smirnov Z & & 0.706603195 \\
\hline Asymp. Sig. (2-tailed) & \multicolumn{2}{|c|}{0.700216509} \\
\hline A & Test distribution is Normal. \\
B & Calculated from data.
\end{tabular}

Dalam uji normalitas data pada Loan To Deposit Ratio (LDR), diperoleh nilai K hitung 0.706603195 dengan nilai signifikan $\alpha=5 \%$, adalah 0.700216509 . Rasio ini memperoleh nilai $\mathrm{P}$ value $>$ dari 0,05 , sehingga dapat disimpulkan bahwa hipotesis Ho diterima bahwa data tersebut berdistribusi normal.

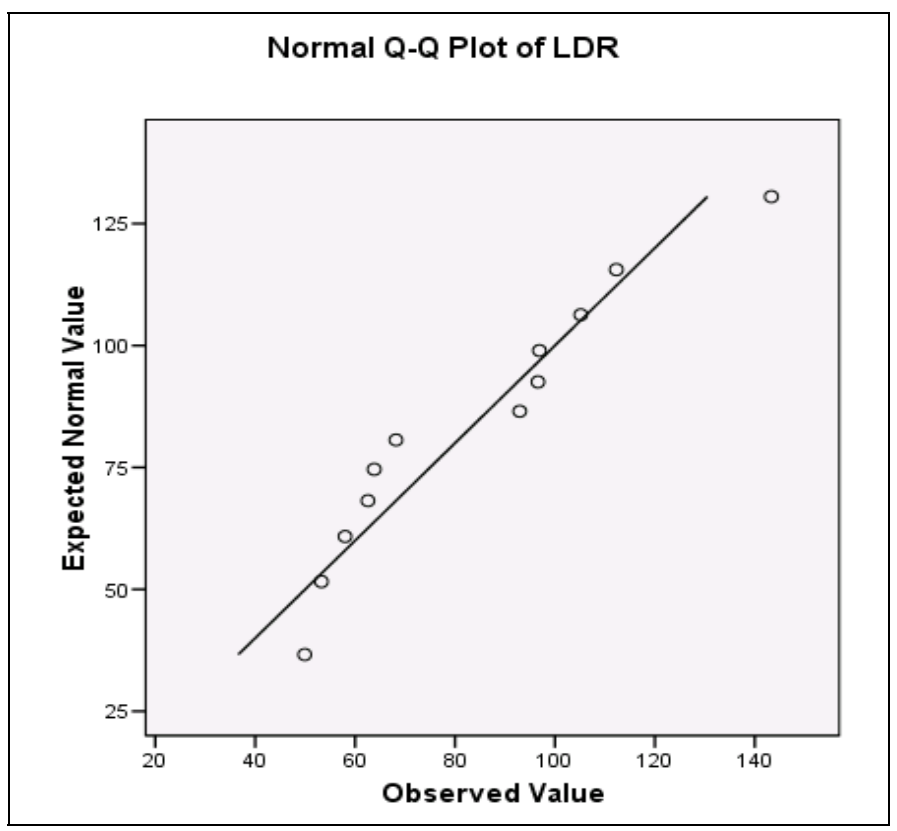

Gambar 5 Normal Q-Q Plot of LDR

Dari rata-rata (mean) LDR disimpulkan distribusi populasi normal karena data berada di sekitar garis normal dan menyebar disekitar garis diagonal 


\section{Pengujian Homogenitas}

\section{CAR}

Tabel 6 Group Statistics CAR

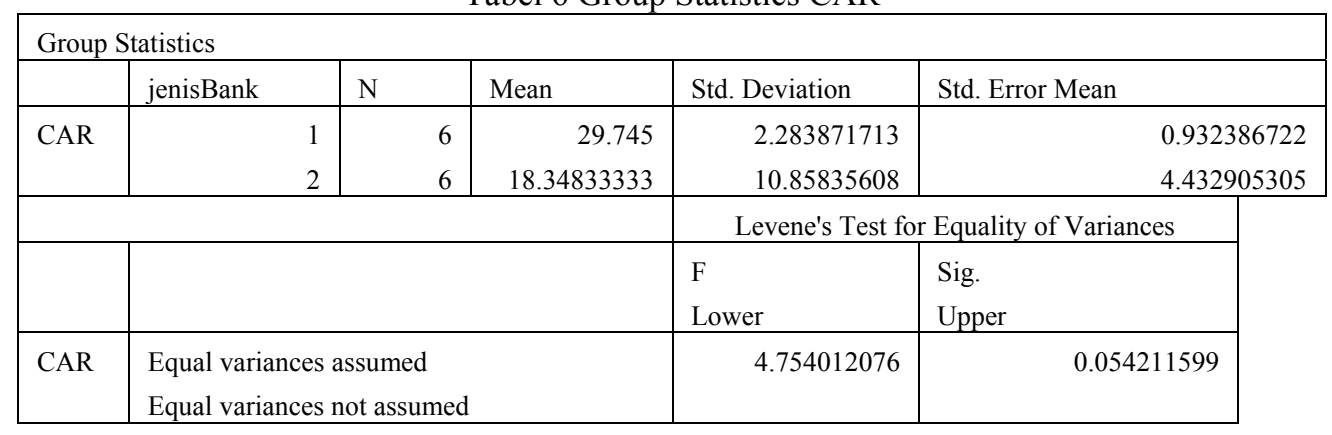

Nilai $\mathrm{P}$ value pada rasio ini menunjukkan nilai signifikansi 0.054211599 artinya $\mathrm{P}$ value dari nilai $\mathrm{F}$ hitung $=4.754012076$ mempunyai nilai yang positif di atas $5 \%$, dengan demikian hipotesis Ho diterima bahwa data tersebut homogen.

\section{NPL}

Tabel 7 Group Statistics NPL

\begin{tabular}{|c|c|c|c|c|c|c|}
\hline \multicolumn{7}{|c|}{ Group Statistics } \\
\hline & JENISBANK & $\mathrm{N}$ & Mean & Std. Devia & & Std. Error Mean \\
\hline \multirow[t]{3}{*}{ NPL } & 1 & 6 & 5.976667 & \multicolumn{2}{|r|}{1.609045266} & 0.656889979 \\
\hline & 2 & 6 & 3.778333 & \multicolumn{2}{|r|}{1.34127427} & 0.547572928 \\
\hline & & & & $\begin{array}{l}\mathrm{F} \\
\text { Lower }\end{array}$ & $\begin{array}{l}\text { Sig. } \\
\text { Upper }\end{array}$ & \\
\hline NPL & $\begin{array}{l}\text { Equal variances assum } \\
\text { Equal variances not as }\end{array}$ & d & & 0.5633 & 0.47021 & \\
\hline
\end{tabular}

Dari hasil perhitungan di atas, diketahui bahwa nilai $\mathrm{F}$ hitung 0.5633 dengan tingkat probabilitas 0.47021 yakni nilai signifikan diatas 5\%. Maka dapat disimpulkan bahwa hipotesis Ho diterima bahwa varians populasi rasio keuangan bank sayariah dan bank konvensional adalah homogen.

\section{ROA}

Tabel 8 Group Statistics ROA

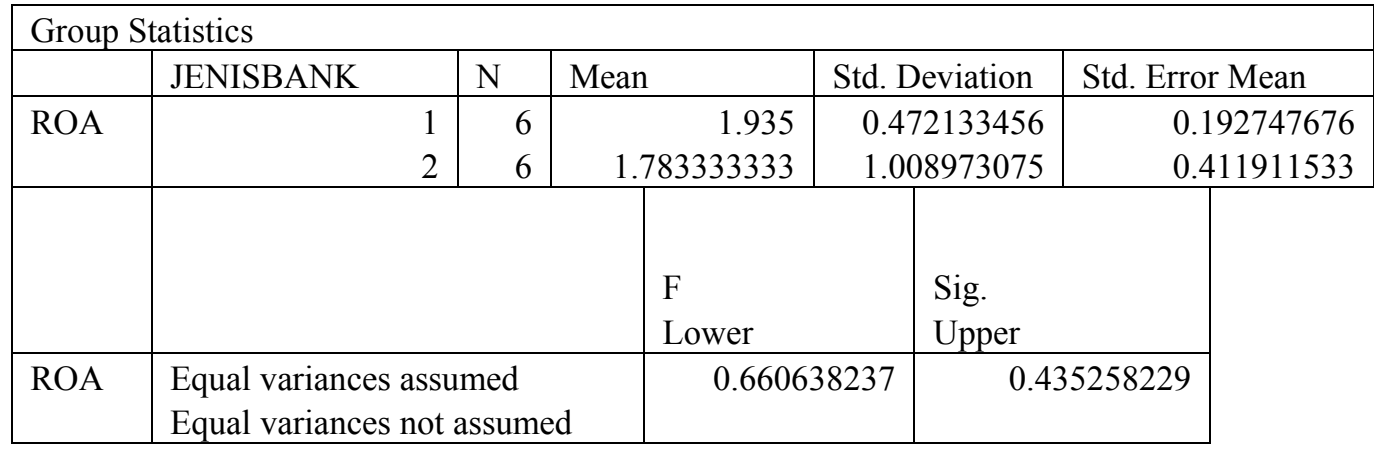


Dari hasil perhitungan di atas, diketahui bahwa nilai $\mathrm{F}$ hitung 0.660638237 dengan tingkat probabilitas 0.435258229 yakni nilai signifikan diatas 5\%. Maka dapat disimpulkan bahwa hipotesis Ho diterima bahwa tidak ada perbedaan dan varians populasi rasio keuangan bank sayariah dan bank konvensional adalah homogen.

\section{ROE}

Tabel 9 Groups Statistics ROE

\begin{tabular}{|c|c|c|c|c|c|c|}
\hline \multicolumn{7}{|c|}{ Group Statistics } \\
\hline & JENISBANK & $\mathrm{N}$ & Mean & Std. & eviation & Std. Error Mean \\
\hline \multirow[t]{2}{*}{ ROE } & 1 & 6 & & & 7.294838358 & 2.978105289 \\
\hline & 2 & 6 & & & 14.24361389 & 5.814931021 \\
\hline & & & & $\begin{array}{l}\text { F } \\
\text { Lower }\end{array}$ & $\begin{array}{l}\text { Sig. } \\
\text { Upper }\end{array}$ & \\
\hline ROE & $\begin{array}{l}\text { Equal variance } \\
\text { Equal variance }\end{array}$ & $\begin{array}{l}\text { assur } \\
\text { not a }\end{array}$ & $\begin{array}{l}\text { d } \\
\text { umed }\end{array}$ & 3.5364 & 0.089444979 & \\
\hline
\end{tabular}

Dari hasil perhitungan di atas, diketahui bahwa nilai $\mathrm{F}$ hitung 3.5364 dengan tingkat probabilitas 0.089444979 yakni nilai signifikan diatas 5\%. Maka dapat disimpulkan bahwa hipotesis Ho diterima bahwa varians populasi rasio keuangan bank sayariah dan bank konvensional adalah homogen.

\section{LDR}

Tabel 10 Group Statistics LDR

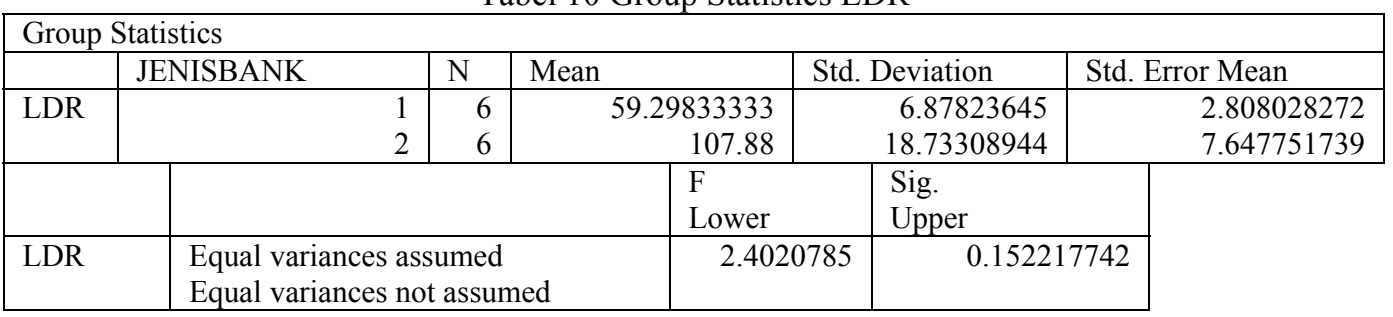

Dari hasil perhitungan di atas, diketahui bahwa nilai $\mathrm{F}$ hitung 2.4020785 dengan tingkat probabilitas 0.152217742 yakni nilai signifikan diatas 5\%. Maka dapat disimpulkan bahwa hipotesis Ho diterima bahwa varians populasi rasio keuangan bank sayariah dan bank konvensional adalah homogen.

\section{Pengujian Beda Independen Sample T-Test}

\section{CAR}

Tabel 11 Group Statistics CAR

\begin{tabular}{|c|c|c|c|c|c|c|c|}
\hline \multicolumn{8}{|c|}{ Group Statistics } \\
\hline & jenisBank & & $\mathrm{N}$ & \multicolumn{2}{|c|}{ Mean } & Std. Deviation & Std. Error Mean \\
\hline \multirow[t]{2}{*}{ CAR } & & 1 & 6 & & 29.745 & 2.283871713 & 0.932386722 \\
\hline & & 2 & 6 & & 18.34833333 & 10.85835608 & 4.432905305 \\
\hline \multicolumn{6}{|c|}{ t-test for Equality of Means } & & \\
\hline \multicolumn{2}{|l|}{$\begin{array}{l}\mathrm{T} \\
\text { Lower }\end{array}$} & \multicolumn{3}{|c|}{$\begin{array}{l}\text { Df } \\
\text { Upper }\end{array}$} & $\begin{array}{l}\text { Sig. (2-tailed) } \\
\text { Lower }\end{array}$ & & \\
\hline \multicolumn{2}{|c|}{2.515875968} & & & 10 & 0.030602881 & & \\
\hline \multicolumn{2}{|c|}{2.515875968} & & 5.44153 & 972 & 0.049567298 & & \\
\hline
\end{tabular}


Oleh karena nilai $\mathrm{t}$ hitung $>\mathrm{t}$ tabel $(2.52>2.228)$ dan dengan memperhatikan nilai probabilitasnya sebesar $0.03(<0.05)$, maka Ho ditolak. Dapat disimpulkan bahwa terdapat perbedaan yang signifikan antara kinerja bank syariah dan bank konvensional. Dengan nilai thitung yang positif menjelaskan bahwa CAR bank konvensional lebih tinggi dibandingkan bank syariah. Melalui deskriptif statistik dipertegas dengan rerata (mean) bank konvensional lebih tinggi dibandingkan bank syariah yaitu 29.75 dan 18.35 .

NPL

Tabel 12 Group Statistics NPL

\begin{tabular}{|c|c|c|c|c|c|}
\hline \multicolumn{6}{|c|}{ Group Statistics } \\
\hline & JENISBANK & $\mathrm{N}$ & Mean & Std. Deviation & Std. Error Mean \\
\hline \multirow[t]{2}{*}{ NPL } & 1 & 6 & 5.976667 & 1.609045266 & 0.656889979 \\
\hline & 2 & 6 & 3.778333 & 1.34127427 & 0.547572928 \\
\hline
\end{tabular}

\begin{tabular}{|c|c|c|}
\hline \multicolumn{3}{|c|}{ t-test for Equality of Means } \\
\hline $\begin{array}{l}\mathrm{T} \\
\text { Lower }\end{array}$ & $\begin{array}{l}\text { df } \\
\text { Upper }\end{array}$ & $\begin{array}{l}\text { Sig. (2-tailed) } \\
\text { Lower }\end{array}$ \\
\hline 2.570595343 & 10 & 0.027862199 \\
\hline 2.570595343 & 9.686043291 & 0.028526734 \\
\hline
\end{tabular}

Hasil yang diperoleh dari perhitungan di atas adalah nilai t hitung $=2.570595343$, dengan standar deviasi yaitu 10, tingkat signifikan yang didapat adalah 0.027862199 dimana nilai tersebut lebih kecil dibandingkan $\mathrm{P}$ valuenya, 5\%. Dan lebih besar dibandingkan $t$ tabelnya 2.228. Dapat disimpulkan Ho yang menyatakan tidak ada perbedaan kinerja bank syariah dan bank konvensional ditolak. Dengan nilai t hitung yang positif menjelaskan bahwa NPL bank konvensional lebih tinggi dibandingkan bank syariah. Melalui deskriptif statistik dipertegas dengan rerata (mean) bank konvensional lebih tinggi dibandingkan bank syariah yaitu 5.976667 dan 3.778333 .

\section{ROA}

Tabel 13 Group Statistics ROA

\begin{tabular}{|c|c|c|c|c|c|}
\hline \multicolumn{6}{|c|}{ Group Statistics } \\
\hline & JENISBANK & $\mathrm{N}$ & Mean & Std. Deviation & Std. Error Mean \\
\hline \multirow[t]{2}{*}{ ROA } & 1 & 6 & 1.935 & 0.472133456 & 0.192747676 \\
\hline & 2 & 6 & 1.783333333 & 1.008973075 & 0.411911533 \\
\hline
\end{tabular}

\begin{tabular}{|l|l|l|}
\hline \multicolumn{4}{|c|}{ t-test for Equality of Means } \\
\hline $\mathrm{T}$ & \multicolumn{1}{l|}{ df } & \multicolumn{1}{l|}{ Sig. (2-tailed) } \\
Lower & Upper & \multicolumn{1}{l|}{ Lower } \\
\hline 0.333496253 & 10 & 0.745647031 \\
0.333496253 & 7.089450194 & 0.748406602 \\
\hline
\end{tabular}

Hasil yang diperoleh dari perhitungan di atas adalah nilai $\mathrm{t}$ hitung $=0.333496253(-\mathrm{t}$ tabel $<\mathrm{t}$ hitung), dengan standar deviasi yaitu 10, tingkat signifikan yang didapat adalah 0.745647031 dimana nilai tersebut lebih besar dibandingkan $\mathrm{P}$ valuenya, 5\%. Dapat disimpulkan Ho yang menyatakan tidak ada perbedaan kinerja bank syariah dan bank konvensional diterima. 
ROE

Tabel 14 Group Statistics ROE

\begin{tabular}{|c|c|c|c|c|c|c|}
\hline \multicolumn{7}{|c|}{ Group Statistics } \\
\hline & \multicolumn{2}{|c|}{ JENISBANK } & $\mathrm{N}$ & Mean & Std. Deviation & Std. Error Mean \\
\hline \multirow[t]{2}{*}{$\mathrm{ROE}$} & & 1 & 6 & 10.82333333 & 7.294838358 & 2.978105289 \\
\hline & & 2 & 6 & 22.47833333 & 14.24361389 & 5.814931021 \\
\hline \multicolumn{7}{|c|}{ t-test for Equality of Means } \\
\hline \multicolumn{2}{|c|}{$\begin{array}{l}\mathrm{T} \\
\text { Lower }\end{array}$} & \multicolumn{2}{|c|}{$\begin{array}{l}\text { df } \\
\text { Upper }\end{array}$} & \multicolumn{2}{|c|}{$\begin{array}{l}\text { Sig. (2-tailed) } \\
\text { Lower }\end{array}$} & \\
\hline \multicolumn{2}{|c|}{-1.783968497} & \multirow{2}{*}{\multicolumn{2}{|c|}{$\begin{array}{r}10 \\
7.454115144\end{array}$}} & \multirow{2}{*}{\multicolumn{2}{|c|}{$\begin{array}{l}0.104749357 \\
0.115010293\end{array}$}} & \\
\hline \multicolumn{2}{|c|}{-1.783968497} & & & & & \\
\hline
\end{tabular}

Hasil yang diperoleh dari perhitungan di atas nilai $\mathrm{t}$ hitung adalah $-1.78398497(-\mathrm{t}$ tabel $<\mathrm{t}$ hitung), dengan standar deviasi yaitu 10, tingkat signifikan yang didapat adalah 0.104749357 dimana nilai tersebut lebih besar dibandingkan P valuenya, 5\%. Dapat disimpulkan Ho yang menyatakan tidak ada perbedaan kinerja bank syariah dan bank konvensional diterima.

\section{LDR}

Tabel 15 Group Statistics LDR

\begin{tabular}{|c|c|c|c|c|c|}
\hline \multicolumn{6}{|c|}{ Group Statistics } \\
\hline & JENISBANK & $\mathrm{N}$ & Mean & Std. Deviation & Std. Error Mean \\
\hline LDR & $\begin{array}{l}1 \\
2\end{array}$ & $\begin{array}{l}6 \\
6\end{array}$ & $\begin{array}{r}59.29833333 \\
107.88\end{array}$ & $\begin{array}{r}6.87823645 \\
18.73308944\end{array}$ & $\begin{array}{r}2.808028272 \\
7.647751739\end{array}$ \\
\hline
\end{tabular}

\begin{tabular}{|c|c|c|}
\hline $\begin{array}{l}\mathrm{T} \\
\text { Lower }\end{array}$ & $\begin{array}{l}\text { Df } \\
\text { Upper }\end{array}$ & $\begin{array}{l}\text { Sig. (2-tailed) } \\
\text { Lower }\end{array}$ \\
\hline $\begin{array}{l}-5.963157257 \\
-5.963157257\end{array}$ & $\begin{array}{r}10 \\
6.324076339\end{array}$ & $\begin{array}{r}0.000138774 \\
0.00082185\end{array}$ \\
\hline
\end{tabular}

Hasil yang diperoleh dari perhitungan di atas adalah nilai t hitung $=-5.963157257$ (t hitung $<-$ $\mathrm{t}$ tabel), dengan standar deviasi yaitu 10, tingkat signifikan yang didapat adalah 0.000138774 dimana nilai tersebut lebih kecil dibandingkan P valuenya, 5\%. Dapat disimpulkan Ho yang menyatakan tidak ada perbedaan kinerja bank syariah dan bank konvensional ditolak. Dengan nilai t hitung yang negatif menjelaskan bahwa LDR bank konvensional lebih rendah dibandingkan bank syariah. Melalui deskriptif statistik dipertegas dengan rerata (mean) bank konvensional lebih kecil dibandingkan bank syariah yaitu 59.298 dan 107.88 .

\section{Rasio CAR}

Rasio kecukupan modal yang menunjukkan kemampuan bank dalam mempertahankan modal yang mencukupi dan kemampuan manajemen bank dalam mengidentifikasi, mengukur, mengawasi, dan mengontrol resiko-resiko yang timbul yang dapat berpengaruh terhadap besarnya modal bank. Perbandingan CAR mulai dari tahun 2002-2007 yang terlihat pada Gambar 5 berikut. 


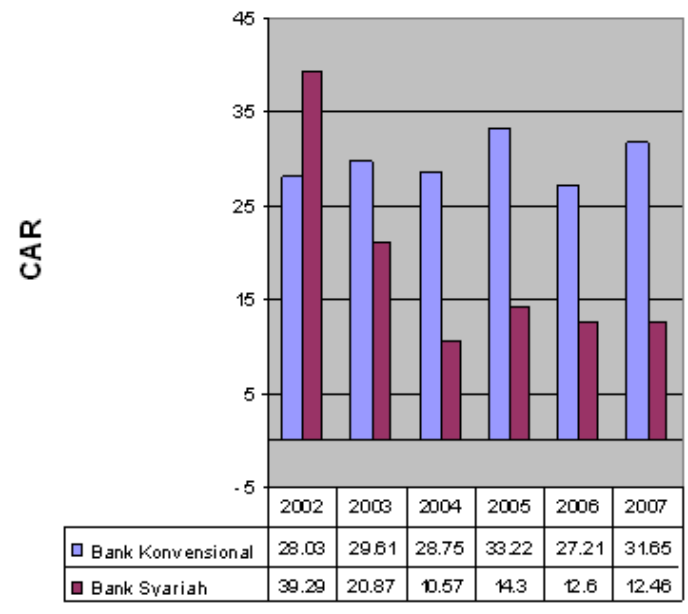

$\square$ Bank Konvensional

Tahun

Gambar 6 Perbandingan CAR dari 2002 - 2007

Pada Gambar 5, rata-rata CAR bank konvensional lebih tinggi dibandingkan dengan rata-rata bank syariah, yaitu $29.745 \%$ dan $18.35 \%$. Kemampuan suatu bank dalam mempertahankan kekayaan dan modalnya yang mencukupi antara kinerja bank konvensional dan syariah cukup signifikan. Mengacu pada ketentuan BI No.3/21/PBI/2001 Pasal 2 tanggal 13 Desember 2001 yang mewajibkan Car mininum $8 \%$ semakin besar semakin baik kinerja suatu bank. Karena nilai CAR kedua industri perbankan tersebut sudah diatas CAR minimum yang diwajibkan oleh Bank Indonesia maka kedua jenis bank tersebut baik bank konvensional maupun bank syariah dinyatakan pada kategori sehat.

\section{Rasio NPL}

NPL atau tingkat kredit macet menunjukan berapa persen kredit yang bermasalah dari keseluruhan kredit ysng mereka kucurkan ke masyarakat. NPL jugs merupakan faktor yang sangat penting bagi penilaian kinerja perbankan, bahkan hampir semua rasio nilainya dipengaruhi oleh NPL. Perbandingan NPL mulai dari tahun 2002-2007 yang terlihat pada Gambar 6 berikut.

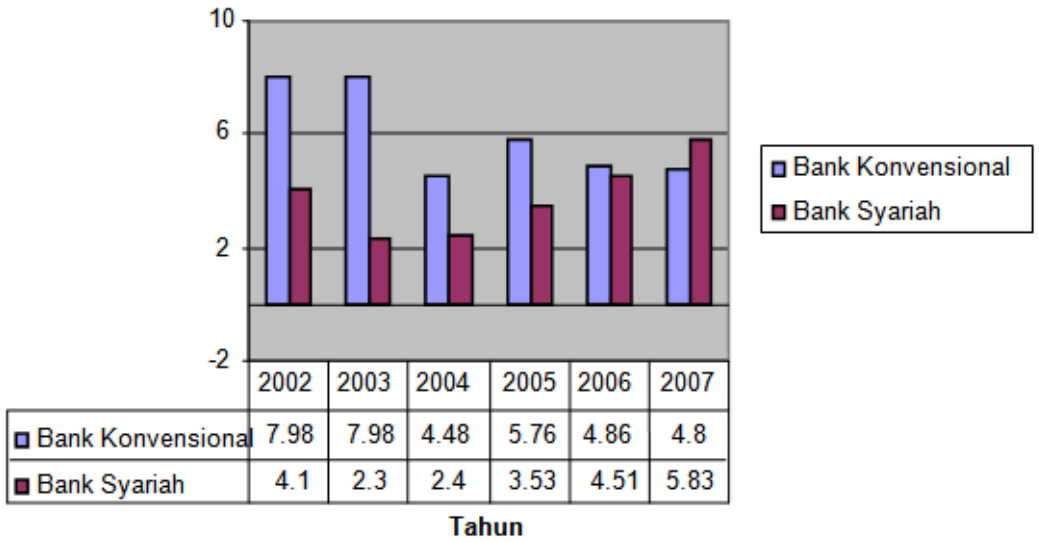

Gambar 7 Perbandingan NPL tahun 2002-2007

Pada diagram diatas, NPL bank konvensional menunjukkan beda yang cukup signifikan. Ratarata NPL bank konvensional lebih besar dibandingkan dengan bank syariah, yaitu $5.98 \%$ dan $3.78 \%$. Mengacu pada Ketentuan BI No.6/23/DPNP tanggal 31 Mei 2004 yang menetapkan NPL max. 5\%, 
nilai NPL Bank syariah mempunyai posisi yang lebih baik dibandingkan bank konvensional. Karena semakin rendah nilai NPL suatu bank akan semakin baik dalam upaya mengurangi kredit yang bermasalah dalam suatu bank.

\section{Rasio ROA}

Rasio ini digunakan untuk mengukur kemampuan manajemen bank dalam memperoleh profitabilitasnya dan upaya manajemen dalam efesiensi secara keseluruhan. ROA digambarkan untuk bank konvensional dan syariah periode 2002-2007 dalam tampilan dalam Gambar 7 berikut.

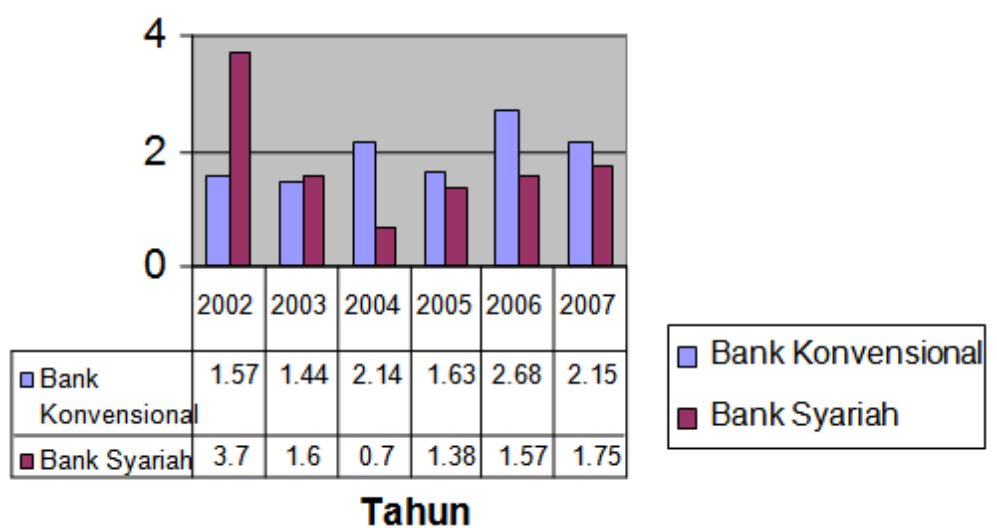

Gambar 8 Perbandingan ROA Bank Konvensional dan Bank Syariah periode 2002-2007

Pada Gambar 7, rata-rata ROA bank konvensional tidak berbeda nyata dengan rata-rata bank syariah, yaitu $1.935 \%$ dan $1.78 \%$. Mengacu pada Ketentuan BI Ketentuan BI No.6/23/DPNP tanggal 31 Mei 2004 berkisar 0.5-1.25\%, nilai ROA kedua bank tersebut baik Bank Konvensional maupun Bank Syariah diatas rata-rata ketentuan BI. Semakin baik kinerja suatu bank semakin besar juga profitabilitas dari pengelolaan modal yang dimiliki. Maka kedua industri perbankan tersebut termasuk dalam kategori bank sehat.

\section{Rasio ROE}

Rasio ini mempunyai arti yang sangat penting untuk mengukur kemampuan manajemen dalam mengelola modal yang tersedia untuk mendapatkan net income. Pada diagram berikut ini digambarkan persentasi ROA bank konvensional dan syariah pada periode 2002-2007.
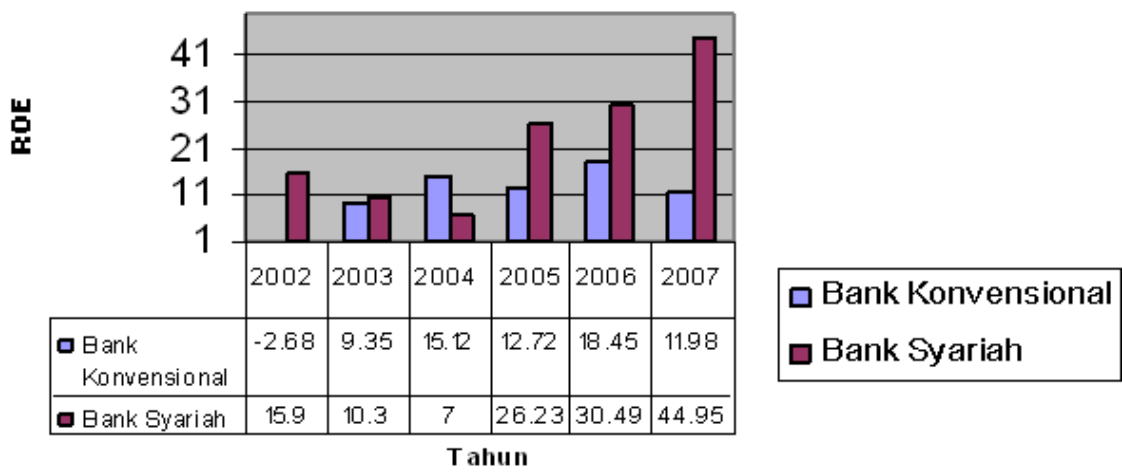

Gambar 9 Persentasi ROA bank konvensional dan syariah pada periode 2002-2007 
Pada diagram diatas, rata-rata bank konvensional dan bank syariah adalah $10.82 \%$ dan 22.48 $\%$. Perbedaan persentasi ROE antara kinerja bank konvensional dan syariah tidak berbeda nyata.

\section{Rasio LDR}

Rasio likuiditas adalah rasio yang menunjukan kemampuan perusahaan dalam memenuhi kewajiban jangka pendeknya termasuk kewajiban jangka panjang yang telah berubah menjadi kewajiban jangka pendek. Salah satu rasio yang digunakan dalam penelitian ini adalah LDR (Loan to Deposit Rasio). Rasio ini memberikan indikasi mengenai jumalh dana pihak ketiga yang disalurkan dalam bentuk kredit (pembiayaan). Naik turunnya rata-rata LDR periode 2002-2007 terlihat pada Gambar 9 berikut.

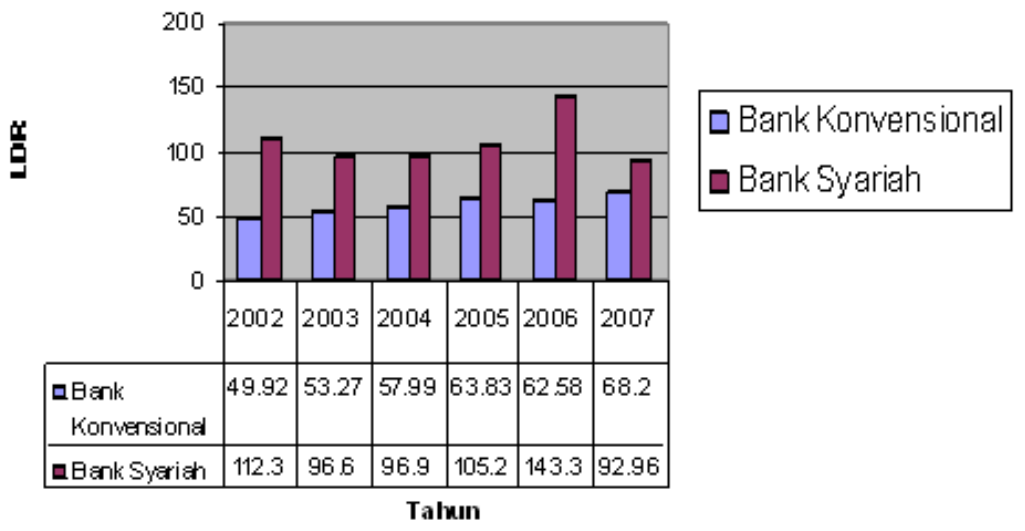

Gambar 10 Rata-rata LDR periode 2002-2007

Pada diagram diatas, terlihat bahwa rata-rata (mean) LDR bank konvensional yaitu 59,3\% lebih rendah dibandingkan dengan rata-rata (mean) LDR bank syariah yaitu 107,88 \%. Perbedaan persentasi LDR antara kinerja bank konvensional dan syariah sangat signifikan. Bank indonesia menetapkan FDR berkisar antara 85-100\%, dari diagram diatas dapat ditarik kesimpulan bahwa bank konvensional memiliki persentasi nilai LDR dibawah $85 \%$ sedangkan bank syariah berada diantara ketentuan BI tersebut. Semakin tinggi FDR semakin meningkatnya ekspansi kredit bank namun tidak diimbangi dengan pengumpulan dana pihak ketiga atau dari sisi lain berarti dana pihak ketiga yang dikumpulkan bank menurun namun jika nilai FDR terlalu rendah terlalu tinggi juga tidak bagus karena menggambarkan kurang baiknya posisi likuiditas bank.

\section{PENUTUP}

Tabel 16 Uji Normalitas Data Kolmogrov-Smirnov

\begin{tabular}{ccccccc} 
Rasio & \multicolumn{2}{c}{ Bank Konvensional } & Keterangan & \multicolumn{2}{c}{ Bank Syariah } & Keterangan \\
\hline & K hitung & Sig. $5 \%$ & & K hitung & Sig. 5 \% & \\
\hline CAR & 0.47 & 0.98 & Normal & 0.76 & 0.6 & Normal \\
NPL & 0.63 & 0.83 & Normal & 0.44 & 0.99 & Normal \\
ROA & 0.59 & 0.88 & Normal & 0.85 & 0.47 & Normal \\
ROE & 0.62 & 0.84 & Normal & 0.44 & 0.99 & Normal \\
LDR & 0.45 & 0.99 & Normal & 0.59 & 0.88 & Normal \\
\hline
\end{tabular}

Dalam uji normalitas data, rasio CAR, NPL, ROA, ROE, dan FDR baik bank konvensional dan bank syariah adalah berdistribusi normal karena nilai signifikan seluruh rasio diatas $5 \%$. 
Tabel 17 Hasil Uji Homogenitas Uji F (Levene's Test)

\begin{tabular}{cccc}
\hline Rasio & F hitung & Sig. $5 \%$ & Keterangan \\
\hline CAR & 4.75 & 0.05 & Homogen \\
NPL & 0.56 & 0.47 & Homogen \\
ROA & 0.66 & 0.43 & Homogen \\
ROE & 3.54 & 0.089 & Homogen \\
FDR & 2.4 & 0.15 & Homogen \\
\hline
\end{tabular}

Dalam uji homogenitas, rasio CAR, NPL, ROA, ROE, dan FDR baik bank konvensional dan bank syariah adalah berdistribusi homogen dengan ketentuan nilai $\mathrm{P}$ value di atas $5 \%$.

Tabel 18 Hasil Uji Beda Signifikan Independent Sample T-Test

\begin{tabular}{cccc}
\hline Rasio & t hitung & Sig. $5 \%$ & Keterangan \\
\hline CAR & 2.5 & 0.03 & Ho ditolak \\
NPL & 2.57 & 0.028 & Ho ditolak \\
ROA & 0.33 & 0.75 & Ho diterima \\
ROE & -1.78 & 0.1 & Ho diterima \\
FDR & -5.96 & 0.0001 & Ho ditolak \\
\hline
\end{tabular}

Dalam uji beda signifikan CAR, dengan membandingkan $t$ tabel dengan $t$ hitung dihasilkan nilai $\mathrm{t}$ hitung $>\mathrm{t}$ tabel $(2.52>2.228)$. Selain itu memperhatikan nilai signifikan sebesar $0.03(\mathrm{P}<$ 0.05), maka dapat disimpulkan bahwa Ho ditolak, atau rata-rata CAR bank konvensional berbeda signifikan dengan bank syariah. Dengan nilai t hitung yang positif menunjukkan bahwa kemampuan bank konvensional dalam mempertahankan modalnya dan kemampuan manajemen bank dalam mengidentifikasi, mengukur, mengawasi, dan mengontrol resiko-resiko yang timbul yang dapat berpengaruh terhadap besarnya modal bank adalah lebih baik dibandingkan bank syariah.

Perhitungan NPL menghasilkan nilai signifikasi di bawah $5 \%$, 0.028. Dan nilai t hitung $>\mathrm{t}$ tabel (2.57>2.228), sehingga membuktikan bahwa antara bank konvensional dan bank syariah adalah berbeda signifikan atau Ho ditolak. Dalam hal ini semakin kecil NPL suatu bank akan semakin baik jika persentase kredit macet dalam bank tersebut akan semakin kecil. Berdasarkan hasil uji beda, nilai NPL bank konvensional lebih tinggi dibandingkan bank syariah yang ditunjukkan dengan $t$ hitung yang positif. Sehingga dapat disimpulkan bahwa bank syariah lebih baik dalam mengantisipasi kredit macet dibandingkan bank konvensional.

Berdasarkan uji beda rasio ROA bank konvensional dan bank syariah mempunyai hasil $\mathrm{t}$ hitung $=0.33(-\mathrm{t}$ tabel $<\mathrm{t}$ hitung), dan nilai signifikan di atas $\mathrm{P}$ value yaitu $5 \%$, yaitu 0.75 . Hal ini membenarkan bahwa Ho diterima, artinya antara ROA bank konvensional dan bank syariah tidak memiliki perbedaan yang signifikan. Dari t hitung yang positif menggambarkan kemampuan manajemen bank dalam memperoleh profitabilitasnya dan upaya untuk melakukan efisiensi oleh manajemen secara keseluruhan bank konvensional tidak berbeda signifikan dibandingkan dengan bank syariah. Dari uji beda ROE, diperoleh nilai $t$ hitung adalah -1.78398497 ( $\mathrm{t}$ tabel $<\mathrm{t}$ hitung). Sedangkan berdasarkan profitabilitasnya menghasilkan nilai signifikan $>5 \%$, yaitu 0.105 . Hal ini juga menunjukkan bahwa Ho diterima, artinya tidak ada perbedaan yang signifikan antara nilai ROE bank syariah dan konvensional. Maka, dapat disimpulkan bahwa Bank syariah dalam mengukur kemampuan menajemen dalam mengelola modal yang tersedia untuk mendapatkan net income tidak berbeda signifikan dibandingkan bank konvensional. 
Pada FDR, nilai $\mathrm{t}$ hitung $=-5.96(\mathrm{t}$ hitung $<-\mathrm{t}$ tabel), berdasarkan profitabilitasnya 0.0001 dimana nilai tersebut lebih kecil dibandingkan $\mathrm{P}$ valuenya, 5\%. Dapat disimpulkan bahwa Ho ditolak, artinya ada perbedaan yang signifikan antara LDR bank syariah dan bank konvensional. Dengan nilai $t$ hitung yang negatif menunjukkan persentasi pengelolaan penyaluran kredit terhadap dana pihak ketiga yang disalurkan oleh bank syariah lebih baik dibandingkan bank konvensional.

\section{DAFTAR PUSTAKA}

Bank Indonesia. (2004). Surat Edaran Bank Indonesia dan Peraturan Bank Indonesia Nomor: 6/10/PBI/2004 Tentang Sistem Penilaian Tingkat Kesehatan Bank Umum.

Chantapong, S. (2003). Comparative analysis of foreign \& domestic bank operation in Thailand: The regression analysis. Journal of Economic Literature (JEL) Classificarion G15, G21, G23, G34.

IBI. (1999). Sistem akuntansi perbankan Indonesia. Jakarta: Institut Bankir Indonesia.

Mudrajat, K. (2002). Manajemen perbankan teori dan aplikasi. Yogyakarta: BPFE.

Sabi, M. (1996). Comparative analysis of foreign \& domestic bank operation in Hungary. Journal of Comparative Economic, Vol. 22 Page 179-188.

Susilo, S. Y. (2000). Bank dan lembaga keuangan. Jakarta: Salemba Empat.

Syahyunan, (2004). Perencanaan, Analisis, dan Pengendalian Keuangan. Medan: USUpress.

Zainuddin, \& Hartono J. (1999). Manfaat rasio keuangan dalam memprediksi pertumbuhan laba: suatu studi empiris pada perusahaan perbankan yang terdaftar di BEJ," Jurnal Riset Akuntansi Indonesia, Vol.2, No.1, Januari, 1999, hal.66-90 